\title{
The Influence of the Partition on the Indian Family in Anita Desai's Clear Light of Day
}

\author{
Noor Isa Abdullatif, MA, \\ Asst. Prof. Isra Hashim Taher, PhD, \\ isra742003@yahoo.com
}

Department of English, College of Arts- Baghdad University

DOI: $\underline{\text { 10.31973/aj.v3i137.1667 }}$

\begin{abstract}
:
Anita Desai's Clear Light of Day (1980) is a partition novel which depicts the influence of the Partition between India and Pakistan on the unity of the Indian family. In 1947, India witnessed a civil war which led to partitioning it into two countries along religious lines. These events coincided with the end of the British rule in India. As a result of that, the Indian individual started questioning his real identity. During the period (1947-1970), India witnessed dramatic social, political, economic changes and transformations In her sixth novel Clear Light of Day, Anita Desai studies the impact of the Partition on the country and on the personal lives of the Indian individuals. The novel is precisely a depiction of family disintegration which parallels the disintegration of India under the Partition circumstances. The aim of the study is to investigate the influence of the Partition on the Indian families which survive the civil wars between the Hindus and the Muslims. Also the study tackles the role of women in the Indian society and the influence of the western principles on them.
\end{abstract}

Keywords: Family, Hindus, Muslims, Partition, Religion Clear Light of Day (1980)

Desai's Clear Light of Day is categorized within the Partition fiction (Osman 15). Partition fiction is a kind of fiction which is associated with the Partition events. The Partition of India inspired many Indian and Pakistani novelists to write about the bloody events which preceded the Partition and their negative impact on the Indians (Sankar 43). Despite that, the novel itself does not revolve around the Partition events directly. Desai comes across some significant incidents of the Partition period, such as the assassination of Gandhi but she does not describe the chaotic circumstances of the Partition closely. More specifically, she does not take the reader into the bloody fights between the Muslims and the Hindus or to the political discussions of that period or how the British dealt with the chaos there. She, instead, focuses on the impact of the Partition on the Indian family. Khan Touseef Osman points out that since the year of 1980, 
the Partition novels have included the "indirect means" to reflect the social chaos which has preceded the Partition. He says that Anita Desai uses siblings' conflict to symbolize the conflict between the Hindus and the Muslims and India and Pakistan. He says also that Clear Light of Day depicts the profound impact of the Partition on the family members (15).

The novel revolves around Raja's brotherly relationship with his two sisters Bimla and Tara, and his rich Muslim neighbor and landlord, Hyder Ali. The book records the return of the younger sister, Tara, to her old home where Bimla and their younger mentally-ill brother, Baba, have been living for many years. The reader is informed that their older brother, Raja, lives in Hyderabad in Pakistan and he is busy with the preparations of his daughter's wedding. The novel is "a memory within a memory," which takes the reader into India in the Partition period depicted in Tara and Bimla's memories when they were children and adults. The narrator moves from the past to the present and vice versa to show the "gender relationship between siblings" under the British's close departure from India (Gairola 122123).

The house of the Das family is located in Old Delhi. For Tara, being in the old house again stirs memories of her childhood before 1947 and after it (Hashmi 56). Tara's reunion with Bimla inspires both sisters to remember the old days of the Das family.

The story starts when the two sisters meet again in their old house in Delhi. They cannot avoid the tension which happens between them because of the differences of their characters. Tara is very reserved, shy and less confident in comparison to Bim (short for Bimla). Bim is strong and highly confident. On the other hand, Tara seems more modern than Bim in appearance. The main issue that they are busy with is Bim's anger at Raja's abandonment and decision to leave for Pakistan. He abandons Bim and Baba as well as his ambition of being a great poet. In her adulthood, Bim volunteers to take care of her family members. She takes care of Baba, and she has taken care of her aunt Mira before her death and Raja in his "deadly illness." With regard to Raja, he admires Hyder Ali, their Muslim neighbor. He inherits his property after marrying his daughter, Benazir, and settling in Hyderabad ( Hashmi 56).

Clear Light of Day reveals the religious prejudice between both the Muslims and the Hindus which was rooted in the Indians' minds for many decades until the period of the Partition. This tension between the Indian castes and religious groups was created by the British strategy of "divide and rule," (Gairola 124).

In "The British Art of Colonialism in India: Subjugation and Division," Aziz Rahman states that British colonizers used many 
strategies in order to rule India successfully. The diverse nature of the Indian society was beneficial to the British colonizers who followed the strategy of "divide and rule," to control India easily. They wanted to exploit the Indian lands by inducing violence between the Indian castes and religious groups. They stirred up civil wars between the Muslims and the Hindus by passing and abolishing certain laws with or against both groups then using propaganda to agitate a civil war. The British were frightened by the unification of the Muslims and the Hindus. When both groups united against the British rule and declared loyalty to the Mughal prince, British colonizers favored the Hindus by improving their educational system and excluding the Muslims from it and the "economic party" to incite hatred between both groups specially that the Muslims were against the British rule (4).

The profound influence of the strategy of "divide and rule" is evident in Hyder Ali's clerck's detestation of Raja's Hindu presence in Hyder Ali's library and aunt Mira's rejection of Raja's decision to accompany their Muslim neighbor (Gairola 123). Raja's frequent visits to Hyder Ali annoy the old man who works as a guard or a clerk in Hyder Ali's library. He looks uncomfortable and seemingly he does not like Raja's presence in the library. Desai expresses the old man's way of thinking of Hindu people by uncovering his thoughts during the moment of Raja's presence in the library:

He presented himself at the Hyder Ali's next day, was shown in by a suspicious servant, waved into the library by a preoccupied Hyder Ali in his office room, and let loose amongst the books and the manuscripts that were to him as the treasure of Haroun al Raschid. He would sit there for hours, daily, turning over the more valuable of Hyder Ali's manuscripts under the watchful eye of an old clerk... who glared, slit-eyed, through his wire-rimmed spectacles at this son of the heathen allowed by some dangerous whim of the rich landlord's to touch holy manuscripts he should not have come near. (Desai 48)

Raja's habit of visiting Hyder Ali's home everyday worries his aunt Mira as well. Desai says describing aunt Mira's behavior, "Aunt Mira seemed as perturbed as the old clerk by this strange friendship," (48). As a Hindu, it seems that aunt Mira does not trust their Muslim neighbor. This reflects the Hindus' mentality at that time especially that this period witnesses a conflict between the Hindus and the Muslims. This conflict forces both groups to distrust each other. Desai herself describes the friendship of Raja and Hyder Ali as a "strange friendship." Basically, because in this particular period it is rare for both groups to be friends. That is why aunt Mira thinks it is dangerous for Raja to accompany Muslims even if they are their neighbor. When Raja starts attending Hyder Ali's gatherings, Aunt Mira frowns. Aunt Mira's expression arouses Bim's curiosity: 
'Why, Mira-masi(aunt)?' Bim asked... Her aunt sat helplessly sucking the thread that dangled from her lips like a fine tail. As she put up her hand to remove it, her hand trembled, 'He should not... It is not safe.' 'They are our neighbor, Mira-masi" Bim exclaimed in surprise. 'But Muslims, it is not safe,' her aunt whispered, trembling. (Desai 56)

Hyder Ali is a generous character which symbolizes the noble Muslims. Hyder Ali is depicted as a charitable, kind and decent man who treats Raja generously without considering his religious background. On the other side, Raja's only concern is having literary knowledge without being indulged in the current religious fight. He detaches himself from reality and lives in the peaceful realm of Urdu and English literature. That is why he is interested in Urdu language more than Hindi language (Gairola 123-124).

Raja always feels himself connected to Hyder Ali's family. He continues meeting the Alis in their evening parties and gatherings and discussing poetry with Hyder Ali. On his part, Hyder Ali treats Raja as his unborn son. Gradually, Raja starts feeling that he is part of Hyder Ali's family and he starts listening to his pieces of advice. When he is a little boy, Raja admires Hyder Ali's nobility and elegance, "Hyder Ali Sahib used to think of himself as some kind of prince.... And Raja loved that," (Desai 25). Hyder Ali notices Raja's interest in poetry that is why he welcomes him as a guest in his night gatherings when his friends recite poetry. Raja attends Ali's night gatherings regularly. Different Islamic issues are discussed in these gatherings which influence Raja's mind and make him interested in the Islamic culture (Sannrud 21).

It is worth mentioning that Raja's interest in Urdu language and Islamic studies are rooted in his mind as a Hindu who is fully aware of the position Urdu language had in the past. Desai explains that Urdu language is considered an elegant language since it was used during the Mughal rule. Even after the fall of the Mughal Empire, Urdu language maintained its position. It was not dangerous for a Hindu man to study the language of Muslims before the Partition, but the case was different during the Partition, "before the Partition ... students had a choice between Hindi and Urdu," (47). This is an evidence about the fact that both Hindus and Muslims used to respect each other and used to live in harmony until the British colonizers used the strategy of "divide and rule" which forced them to fight each other and disrespect each other's culture. Because of the religious conflict, Raja's choices become limited. His father is fully aware of the disastrous situation that the Indians go through in this particular period. For this reason, he opposes his son's decision. 
Rituparna Roy comments on the father's advice: "This passage in the novel alerts us to the fact of how the spectra of the Partition was affecting one and all on the subcontinent in 1947," (84). With regard to Raja, he seems surprised by his father's opposition which shows to which degree Raja is detached from the social reality for this reason he does not understand his father's point and exclaims who would hurt him if he follows Ali's advice "Who will do that to me?" (Desai 52). His father knows the consequences of his son's choice, that is, both groups, the Hindus and the Muslims, would not trust him. He assures him that both groups will distrust him, "... Muslims for trying to join them,... And Hindus for deserting them," (52).

Both Raja and Bim used to be close to each other before Raja's decision of departing for Hyderabad. After receiving a letter from Hyder Ali who has left to Pakistan, Raja decides to leave for Pakistan to help Hyder Ali in his business. Bim is offended by his decision specially that she has nursed him in his illness. Further, the antagonism between the two siblings increases after the death of Hyder Ali. Raja sends a letter to Bim saying that she can stay in the house as long as she pays the rent that the family always paid. Bim finds this letter offensive. It increases her rage. The hostility between both siblings parallels the hostility between Muslims and the Hindus and India and Pakistan (Osman 18).

The Partition catastrophic events cause physical damage and cost the Indians' lives. But what Desai focuses on is the trauma that the survivors encounter during and after the bloody events. This trauma affects the survivors' psyche and instigates the survivors' unconscious behavior of repeating acts similar to the acts which have caused the trauma. Tarun Saint says referring to Freud's explanation of the influence of the trauma:

The traumatic experience repeats itself through the unknowing acts of the survivors, sometimes against their will. Trauma...is a wound afflicted not only upon the body but also on the mind... the wound on the mind is often experienced too soon, too unexpectedly to be known, and is thus not available to consciousness until it imposes itself again repeatedly in the nightmares and repetitive actions of the survivor. Trauma is thus not merely located in the simple violent or original event in an individual's past, but rather in its unassimilated nature and the way in which it was precisely not known in the first instance returns to haunt the survivor later on (199).

Saint relates Freud's understanding of the concept of trauma to Raja's act of deserting his siblings. The Partition's bloody events are stuck in his subconscious mind which forces him to recreate similar events unconsciously. He is not damaged physically, but the memory of the Partition events damages his psyche thus he acts in this way to 
reconnect the remnants of the destroyed culture. Mainly, the victims of the Partition events are the Muslim community, but Raja is considered a victim as well due to the drastic incidents in India which influence him. He unconsciously cuts his ties with Bim and Bim does the same thing as a reaction, the very thing that happens with the Muslims who insist on separating themselves from the Hindus and vice versa (199-200).

In addition to what Saint says, Raja is obsessed with the Islamic Indian culture. Literally, he leaves to Pakistan because he admires Hyder Ali, but symbolically, Hyder Ali represents the Islamic culture which is about to be lost in India because of the Partition. Raja as a Hindu who appreciates the Islamic culture as a part of the Indian culture does not want to lose his connection with it. Desai explains the importance of Urdu language: "Urdu had been the court language in the days of the Muslims and Moghul rulers and had persisted as the language of the learned and the cultured," (Desai 47).

Desai reveals how the colleges became a nest for discussing politics and for conspiring against the enemies in the Partition period. Also she reflects the situation of the Hindus like Raja who support Muslims. The fanatic Hindus are ready to fight even the Hindu people who separate themselves from the religious fight or those who support Muslims. Raja discovers that his Hindu friends in the college are against the decision of dividing India and establishing a country for the Muslim minority. Despite that, he naïvely shows his sympathy for the Muslims openly. On the other side, his Hindu friends expect him to be a revolutionary Hindu man who would stand with their cause. For this reason, they try to convince him to join them to enlarge their organization against the Muslims. Instead, they find him sympathized with their Muslim enemies. They start distrusting him and conspiring against him for his weird interests in the Islamic culture that is why they consider him a dangerous enemy (Roy 85). Desai comments:

Raja, whose home and family gave him an exceptionally closed and sheltered background, was slow to realize this. The boys had taken him to teashops and given him cigarettes..., he had gone to cinema shows with them, sung songs with them as they cycled back at night. Now they were strangely and abruptly altered. When he spoke to them of Pakistan as something he quite accepted, they... called him a traitor. (57)

Raja's character is the incarnation of Desai's thoughts and point of view. Raja does not only represent the peaceful Hindus but he is made to interpret Desai's wish for a peaceful home which embraces people from different religions and cultures. Raja, Desai and the famous national figure Gandhi share some thoughts and characteristics which could be the core of the novel. Anita Desai used to attend a 
school near her home which was Christian and English. In the school, she was introduced to the Urdu language and the heritage of the Islamic culture that her country had. She met Hindu and Muslim students in the school for this reason she said describing India that it embraced many different cultures which were combined harmoniously before Independence," "For the most time I've lived in India, in a home where cultures combined rather than clashed. " (qtd. in Sannrud 7). Raja's character is the representation of the harmonious relationship between the different cultures in a single country. Though he is a Hindu, but he accepts the Islamic culture as a part of the Indian glorious history. Being a Hindu and an admirer of the Islamic culture, Raja symbolizes the peaceful combination of cultures that Desai hails and wishes for like Gandhi, the national figure who had the same thoughts earlier.

Gandhi is mentioned once or twice in the novel, but surely the presence of his name has a symbolic meaning. Gandhi believes in an India where all races and classes live in harmony. He said referring to the Hindu and Muslim communities "our endeavour should be to create the necessary atmosphere of harmony to enable the two communities to live together," (qtd. in Kripalani 260). Both Gandhi and Desai seemed positive about the harmonious combination of the different Indian cultures in India and apparently both of them were against partitioning India. Raja represents the loop which links both partitioned cultures and the core of Gandhi and Desai's message. For this reason, Raja is attached to the Islamic culture through Hyder Ali and attached to Hindu culture through Tara who continues contacting her brother.

Each member of the Das family acquires a different identity after the Partition which contributes to transforming each one of them to a different person. This transformation is the clear result of the Partition from one side and the influence of the British culture on the other side. Further, this transformation contributes to separate the family and create a tension between them. Raja is not the only one to be influenced by the Partition events. Bim used to be the closest sibling to Raja, she used to recite poetry with him and she used to praise his poems. Now after many years of the Partition and Raja's departure for Pakistan, Bim mocks Raja's poem before Tara. This shows how she is transformed and that the many years of Raja's departure harden her heart towards her brother. The conversation between Tara and Bim reveals the tension between Bim and Raja:

She (Tara) said:' ... d'you remember Raja marching up and down here on the roof, swinging his arms and reciting his poems... I used to feel like crying, it was so beautiful- those poems about death, and love, and wine, and flames.' ' They weren't. They were terrible,' 
Bim said icily, tossing her head with a stubborn air, like a badtempered mare's. 'Terrible verses he wrote.' (Desai 25)

Raja's departure paves the way to Bim to have a leading independent character which is unfamiliar in the Indian society. The Indian women's mentality was also influenced and changed because the British colonizers imposed their cultural principles on the Indian society. Ramesh Kumar Gupta states that women today reject the concept of "Angel in the house" and revolt against the traditional image of the woman. The "new woman" is aware of the social belief which is women have a lower position in the family (152). Therefore, this new woman decides to fight the old traditions and turn against the restricted norms and currents. Thus, Meera Bai defines the concept of the "New Woman,"

The word New Woman has come to signify the awakening of woman into a new realization of her place and position in family and society. Conscious of her individuality, the new woman has been trying to assert her rights as a human being and is determined to fight for equal treatment with man." (qtd. in Devi and Sanasam 165).

Anita Desai's female characters are not only revolutionary but also they are strong enough to face the consequences of their decisions. Desai says, "I'm interested in characters who are not average but retreated or been driven into some extremity of despair and so turned against,... the general current," (qtd. in Gupta 153). Bim is an exceptional woman in comparison to other female characters in the novel. She has a leading and an independent personality. She believes in her individuality and ability to depend on herself in leading her life instead of being led by a man. Neeru Tandon believes that because of Bim's individuality and self-reliant personality, men like Biswas and Bakul (Tara's husband) admire her. On the other hand, Bim refuses to marry Dr. Biswas to protect her independence (49-50).

In her childhood, Bim shows her interest in man's world. She decides to enter Raja's room, checking his male stuff and wearing his clothes. The act of wearing male clothes foreshadows Bim's decision to be an independent woman who challenges the male world. In addition to that, it shows her awareness of her position as a "new woman" in her family where she is treated as inferior to Raja. When she holds up Raja's trousers at her waist, she tells Tara that she looks as tall as Raja, "look, Tara, I'm nearly as tall as he is now," (Desai 131). This indicates that she believes, as a woman in being equal to Raja who is the representative of male superiority. Tara rejects Bim's statement, she answers her, "No, you are not,... They're much, much too long,"(132). Tara's rejection represents the rejection of the society which considers women inferior to men. Both girls like the idea of wearing male clothes which makes them conscious about their inferior 
position. The trousers symbolize "masculinity and superiority." Both Tara and Bim try to acquire a new identity which is more superior through wearing Raja's clothes (Heidari and et al 35).

Suddenly they saw why they were so different from their brother, so inferior and negligible in comparison: it was because they did not wear trousers. Now they thrust their hands into their pockets and felt even more superior- what a sense of possession, of confidence it gave one to have pockets, to shove ones' fists into them, as if in simply owning pockets one owned riches, owned independence. (Desai 132)

Bim is an epitome of the Indian woman in whom the British principles are implanted. As a little girl, Bim enjoys the role of a leader in her school. She works on asserting her independent identity which is considered a hybrid identity (Stoican 47):

At school Bim became a different person - active, involved, purposeful. A born organiser, she was patrol leader of the Bluebirds when still a small pig-tailed junior, later of the Girl Guides, then captain of the netball team, class prefect, even - gloriously, in her final year at school - Head Girl...To Bim, School and its teachers and lessons were a challenge to her natural intelligence and mental curiosity that she was glad to meet. (Desai 122-123)

She enjoys being an affective figure in the society. She rejects the idea of being treated as an outsider, she insists on participating in the social activities and changing the society. In comparison to Tara, Bim is very strong in character and she is very ambitious. On the other side, Tara hates school. She always isolates herself and does not want to participate in any activity, the very thing that annoys Bim. When Tara complains about serving the sick in the hospital, Bim scolds her for her weak personality and reveals the new woman's goal in which is not to be isolated or kept in the house, she wants to have a significant contribution to society that is why she does not like Tara's weakness which is found in any traditional woman:

Too fine a lady to step into the hospital ward? The smells upset you, do they? The sights keep you awake at night, do they? Oh, you poor little thing, you'd better get a bit tougher, hadn't you- auntie's baby? Otherwise what good will you ever be? If you can't even do this little bit for the poor, what will you ever be able to do when you grow up? (Desai 126)

Elena Stoican explains that according to the Hindu traditional belief that women's job in life is to serve her husband and children. Further, the Hindu women are conceived as weak creatures who need to be protected by men and that they are unable to lead an independent life by themselves (44). While Tara is shown as somehow a 
traditional Hindu woman who needs a man to protect her, Bim rejects this identification and decides to challenge it.

The difference between the two sisters appears early. Tara shows her interest in being a mother, while Bim mocks her and she echoes Raja's future dream of being a hero. Bim struggles to abolish "her imprisoning female condition," (Stoican 47). She strives to impose her thoughts while she is surrounded by people who do not believe in the Indian woman's individuality including the women she knows in her life and this makes her mission even harder. Education and independence might not be the traditional woman's interest, the very thing which angers Bim. When the Misra girls (their neighbor) decide to marry at the ages of sixteen and seventeen, Bim protests, believing in the importance of education which is more important to her than marriage:

'But they are not educated yet... They haven't any degrees. They should go to college... because they might find marriage isn't enough to last them the whole of their lives' 'What else could there be?' countered Tara.' 'What else?' asked Bim. 'Can't you think? I can think of hundreds of things to do instead. I won't marry,' she added, very firmly. 'I won't,' repeated Bim, adding 'I shall never leave Baba and Raja and Mira-masi'... I shall work -I shall do things,' she went on, 'I shall earn my own living and look after Mira-masi and Baba and - and be independent. (Desai 140)

Bim's individuality is the direct reason behind her refusal of Dr. Biswas' marriage offer. She analyzes his personality and discovers that he is highly traditional in his worldview and thoughts about women. Although he is a doctor, he always seems hesitated and lacks confidence which motivate Bim to mock him. Dr. Biswas fails in understanding the reason why Bim mainly rejects him. She notices that he "behaves in the typically patriarchal way of keeping women down," Dr. Biswas angers Bim when he thinks that Bim's ultimate aim is to serve her family as the traditional woman usually does (Heidari and et al 36). He tells her:

'Now I understand why you do not wish to marry. You have dedicated your life to others to your sick brother and your aged aunt and your little brother who will be dependent on you all his life. You have sacrificed your own life for them'... Bim's mouth fell open with astonishment ...She even hissed slightly in her rage and frustration at being so misunderstood, so totally misread, then gulp a little with laughter at such grotesque misunderstanding, and her tangled emotions twisted her face and shook the thought of Biswas out of her. (Desai 97)

Clearly, Bim does not want Dr. Biswas to think that she is an "angel in the house." And that her job is to cook for her family, and 
nurse the sick ones of them and do other household stuff. She is even not interested in feminine world contrary to Tara who has female interests like shopping and cooking.

Bim gives the credit of her college degree to herself. As a woman who lives in a patriarchal society, she educates herself and no one encourages her to do that. Her father does not encourage her to continue her education. Thus, she becomes a professor of history at women's college by her efforts and she earns her living and independence. Like Raja, who is used by Desai to break the boundary between the Hindus and the Muslims, Bim is also used to break the boundary between women and men and abolish the belief in women as being inferior. Bim refuses to marry because she does not want to be treated as the "other," (Devi and Sanasam 168).

Bim as a new woman is aware of how she was marginalized by her father. He has not bothered himself to teach her about his business in his company, instead he has taught Raja. Raja refuses to lead his father's business and leaves for Pakistan that is why Bim suffers while she is trying to lead her father's business after his death because she does not have any experience to lead it. She criticizes her father who is the representative of the patriarchal society which treats women as "other". She says "Father never bothered to teach me. For all father cared, I would have grown up illiterate - and cooked for my living or swept. So I had to teach myself history and teach myself to teach. But father never realized- and Raja doesn't realize," (Desai 155). For this reason, Bim plays the role of a missionary who wants to implant her way of thinking in people to enlighten them. Bim does not only teach her female students history, but she also teaches them how to be a new kind of women "... I'm always trying to teach them, train them to be different from what we were (her and Tara) at their age- to be a new kind of woman from you and me," (155).

When Bim becomes a full grown woman, she breaks all the traditions and the social norms which restrict women and she does all what she wanted to do when she was a little girl. She grows more confident, independent and becomes an educated woman. Gupta believes that the direct reason behind Bim's individuality is that Bim's parents barely existed in the house. They spent most of the time outside the house playing cards or doing business so they were not that kind of parents who used to instruct their girls and to teach their traditional role. She says that Bim had (as a little girl) the free will to choose her way of thinking and she chose to be independent (156).

Bim is aware of her traditional role but at the same time, she believes her traditional role is not her ultimate aim in life. She is unlike her aunt Mira and Tara, she can provide what she needs without relying upon "masculine forces." Bim is the woman whom 
Simon de Beauvoir describes in the following terms: "Once she ceases to be a parasite, the system bases on her dependence crumbles; between her and the universe there is no longer any need for a masculine mediator," (qtd. in Gupta 158).

Like her older siblings, Tara is caught between two choices which are whether to be submissive or to be practical and rational. In fact, Bakul, Tara's husband is influenced by the western thoughts which have been brought by the British colonizers. He struggles to make Tara practical, rational and highly confident. For this reason he always admires Bim for her individuality, rationality and self confidence and Tara is fully aware of Bakul's feelings towards her sister. At the same time Tara always admires Bim's courage and ability to follow a very new way of life in India which seems hard for Tara to do because she suffers from low self-esteem. Ironically, Tara pretends rationality and practicality only to satisfy Bakul, thus this is another kind of submission. She hides her true nature because she is ashamed of it. She even considers her two daughters far better than her culturally and that her rustic culture is inferior to the western culture which is acquired by her two daughters while they have lived in America:

Now and then one (fruits) fell to the ground with a soft thud ... If she had been younger- no, if she had been sure Bakul would not look out and see- she would have run down the veranda steps and searched for one that was whole ...She wondered if her girls would do it... No. they would not. Much travelled, brought up in embassies, fluent in several languages, they were far too sophisticated for such rustic pleasures, she... felt guilty over her own lack of that desirable quality... She had fooled Bakul into believing that she had acquired it, that he had shown her how to acquire it. But it was all just dust thrown into his eyes. (Desai 11-12)

Elena Stoican discusses Tara's childhood and her detestation of school. Tara is totally different from Bim who enjoys the world of the school. Tara does not like the atmosphere of the school. She always wants to stay at home which is a small space to her. The school for Tara is wide and large and that it embraces various forces which mock her and laugh at her shy and boring character, "school to Tara was a terror, a blight, a gathering of large, loud, malicious forces that threatened and mocked her fragility (Desai 123). The "friendship with the loud, vulgar, vigorous young girls in the class, so full of unpleasant secrets and revelations,"(123) are unpleasant to Tara. (Stoican 48-49). She is always excluded from any gatherings in the school. She is always treated as an outsider.

Tara's lack of interest in the world of the school suggests that she prefers her traditional role by protecting herself in the small space 
which is called home. It also suggests that she needs a "motherly protection," (Stoican 49), "she hoped never to have to do anything in the world, that she wanted only to hide under Aunt Mira's quilt," (Desai 126). Students in school consider Tara "snobbish and conceited"(125) only because she isolates herself from them.

Tara's weakness also is embodied in her rejection to feed the poor in the hospital. Her hatred of the dismal atmosphere of the hospital suggests that she is too weak to participate in the social activities outside her home. She is unable to encounter the hardships of the life that is why she prefers to isolate herself rather than face the reality of life. At the same time, she does not want to be responsible for her family members that is why she marries Bakul (Stoican 49). Tara proves that she has no courage to face difficulties in life, that is why she always prefers to escape them:

The kind of atmosphere that used to fill it when father and mother were alive, always ill or playing cards or at the club, always away, always leaving us out, leaving us behind- and then Mira-masi becoming so-so strange, and Raja so ill- till it seemed that the house was ill, illness passing from one generation to the other so...the only thing to do was to get away from it, escape.... (Desai 156)

The previous passage shows Tara's need for someone to embrace her weakness and to protect her that is why she chooses Bakul to depend on and this characteristic is found in the traditional woman who is believed to be in need of an authority to obey and follow. She blames her parents for not being by her side and that is why she welcomes the decision of marriage because it provides her with a masculine authority which is embodied in Bakul. Thus Tara cannot be considered a "new woman."

Tara is always excluded from her siblings' world. In other words, they do not take her seriously most of the time and treats her as an outsider, "She had always stood on the outside of that enclosed world of love and admiration in which Bim and Raja moved, watching them, sucking her finger, excluded," (Desai 26). Had they treated her seriously and involved her with them she would have been another person, a person likely more confident and would not feel that she is an outsider in every place she goes, in school or in hospital. She would not feel that all people do not take her seriously and that they always mock her.

Both Bim and Tara live a different childhood which shapes their personality, Desai says, "to look at Bim one would not think she had lived through the same childhood, the same experiences as Tara," (23). While Bim is given the confidence and self-assurance through her close relationship with Raja who pays her a great attention, cares for her opinions and shares with her his interests, and through Hamid, 
Raja's friend who allows her to play with him and Raja, Tara is not treated the same. Almost no one pays her attention that is why she is impressed by Bakul before her marriage because he pays her attention, "'At that time I was just- just swept off my feet... Bakul was so much older, and so impressive, wasn't he? And then, he picked me, paid me attention- it seemed too wonderful, and I was overwhelmed ,'" (Desai 156). Gupta agrees that Tara's decision of marriage is because of the lack of attention she receives in her home (158).

Despite Tara's traditional way of thinking, Gupta believes that Tara also reacts "in radical ways to the set of conventional construct." Despite Tara's continuous obedience to her husband, she is aware of her blind obedience and sometimes questions it (158), a characteristic not found in the traditional woman. She comes to a realization that she does not like to be controlled by Bakul each time. She intentionally refuses to obey Bakul when he commands her to join him going to one of his cousins. She feels that she cannot continue following him blindly forgetting herself or her identity, "She felt she had followed him enough, it has been such an enormous strain, always pushing against her grain, it had drained her of too much strength, now she could only collapse inevitably collapse," (Desai 18).

Tara has the awareness of "the new woman" at the same time she behaves as the traditional woman most of the time. She is in between, she cannot be considered similar to her aunt Mira, who welcomes her role as a traditional woman.

At the end, Bim forgets her brother Raja. She tells Tara to inform Raja to visit her. This suggests that there is a ray of hope for the family to gather again. Symbolically, Bim's forgiveness is like an invitation of a Hindu from India to a Muslim from Pakistan to gather again as Individuals who belong to the same house (India).

\section{Conclusion}

Clear light of Day is a study of a wide range of cultural issues which overlap with each other, issues related to religion, woman's position, literature, languages and nationality. The most important theme in the novel is the Partition theme. Despite the fact that the Das family has survived from the bloody events of the Partition, they get hurt psychologically and deeply. Because of the Partition, Bim departs her close brother, Raja, and her sister Tara, for many years. Bim is angry because her family is disintegrated because of the Partition. Raja who is a Hindu, has a very deep relationship with Haider Ali's family that is why he is forced to leave for Pakistan with them. On the other hand, Tara and her husband immigrate to the west after Partition. The Das family stands for the Indian family and its situation after the Partition. The novel shows the indirect negative impact on the survival families of India. 


\section{Works Cited}

Desai, Anita. Clear Light of Day. Is ted. Boston: A Mariner Book, 1980. Print.

Devi, Khuraijam Artishowri, and Reena Sanasam. "The Concept of New

Woman in Anita Desai's Clear Light of the Day and Manju Kapur' Home." The Echo 2. 3 (2014): 165-177. Web. 22 May 2019.

Gairola, Rahul K. "A Partition Without Borders: Diasporic Readings of Clear Light of Day and Train to Pakistan." Crossing Borders: Essays on Literature, Culture and Society in Honor of Amritjit Singh, eds. Tapan Basu and Tasneem Shahnaaz. London: Rowman \& Littlefield, 2017.Print.

Gupta, Ramesh Kumar. "The Concept of 'New Woman' in Anita Desai's Clear Light of Day." Critical Essays on Anita Desai's Fiction. Ed. Jaydipsinh Dodiya. Ist ed . New Delhi: IVY Publishing House 2007. Print.

Hashmi, Alamgir. "A Reading of Anita Desai's Clear Light of Day." The International Fiction Review1o.1(1983): 56-58. Web. 8 May 2019.

Heidari,, Marjan, et al. “Women's Struggle for Identity in Anita Desai's Clear Light of Day." The International Journal of the Humanities, 9.3 (2011): 32-39.Web. 9 Jan 2019.

Kripalani, J B. Gandhi His Life and Thought. New Delhi: Today \& Tomorrow's Printers and Publishers, 1970. Print.

Osman, Khan Touseef. "Representing the Unrepresentable in Anita Desai's Clear Light of Day." East West Journal of Humanities, 5(2015): 15-23. Web. 8 July 2019.

Roy, Rituparna. South Asian Partition Fiction in English: From Khushwant Singh to Amitav Ghosh. Amsterdam: Amsterdam University Press, 2010. Print.

Saint, Tarun K. Witnessing Partition: Memory, History, Fiction. New Delhi: Routledge, 2010. Print.

Sannrud, Kirsti Weel. "Themes, Symbolism and Imagery in Anita Desai's Clear Light of Day." Diss. U of Oslo, 2008. Web. 10 Jan 2020.

Stoican, Elena. "Indian Female Identities, Between Hindu Patriarchy and Western Missionary Models in Anita Desai's Fasting, Feasting and Clear Light of Day." University of Bucharest Review. 5.2(2015): 43-52. Web. 16 June 2019. 
تأثثر التقسيم على العائلة الهندية في رواية "ضوء نهار مشرق" لانيتا ديساي

الباحثة نور عيسى عبد اللطيف، قسم اللغة الانكليزية، كلية الاداب

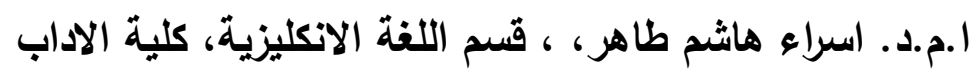

المستخلص

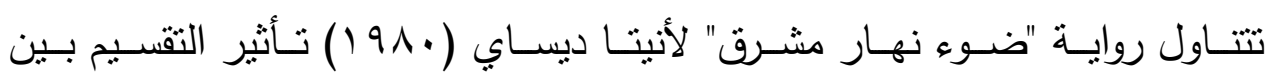

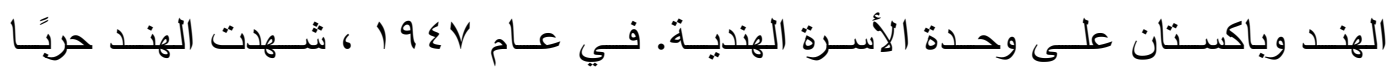

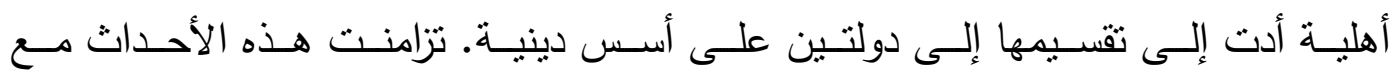

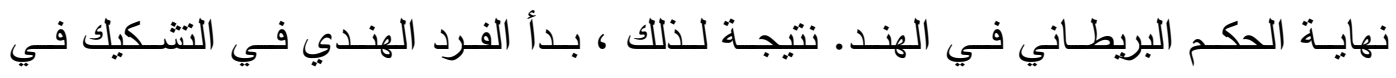

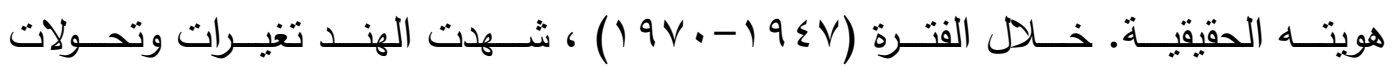

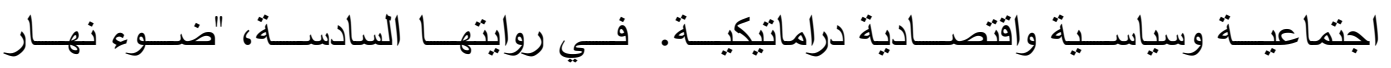

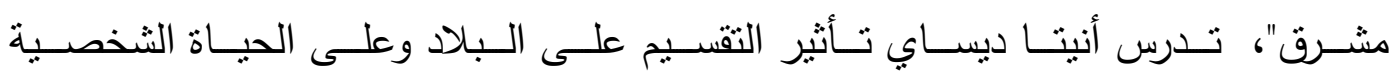

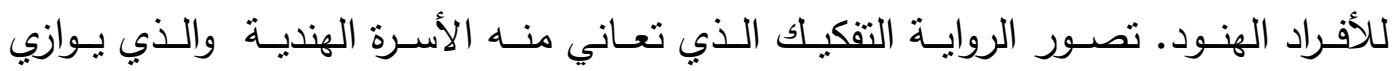

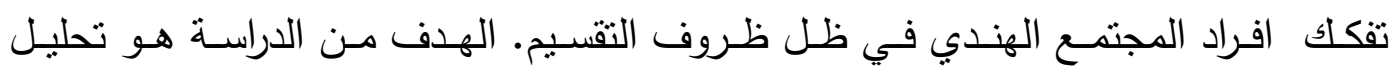

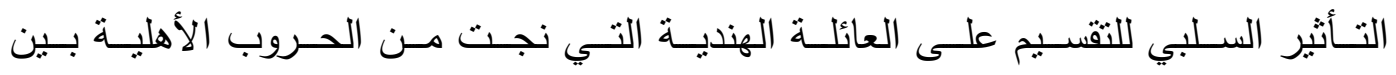

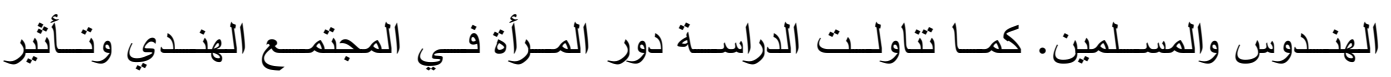
المبادئ الغربية عليها. كلمات مفتاحية: العائلة، الهندوس، المسلمون، التقسيم، الدين 